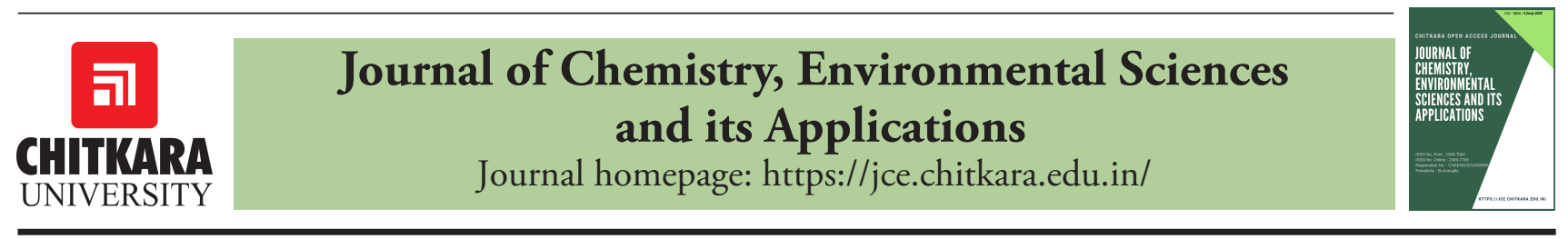

\title{
Stubble Burning in North-West India and its Impact on Health
}

\author{
Ms Charu Batra \\ Research Scholar, Centre for Research in Rural and Industrial Development. Sector 19-A, 160 019, Chandigarh, India \\ Email: chrbatra@gmail.com
}

\section{ARTICLE INFORMATION}

Received: 13 August 2017

Revised: 21 August 2017

Accepted: 27 August 2017

Published Online: September 6, 2017

Keywords:

Crop Residue, Stubble Burning,

Acute Respiratory Infection, Air Quality Index

DOI: https://doi.org/10.15415/jce.2017.41002

\begin{abstract}
Burning of crop residues released many pollutants, resulting in serious health hazards. This paper is an attempt to explore status of crop residues burning in Northwest India and its consequences on health in general and on child health in particular. An effort has also been made to find out the correlation between stubble burning and increasing incidence of acute respiratory infection (ARI) among children in Punjab. Finally an inventory of suggestions to curb this evil has also been prepared. Based on secondary sources, the data collected from various published studies, reports and NFHS, the present study found that residue burning resulted in the emission of greenhouse and various harmful gases. Such emission of harmful gases is many times higher than the standard level of gases as recommended by Central Pollution Control Board (CPCB). It has also been observed that the phenomenon of stubble burning is quite high in Punjab with comparison to other northwest Indian states resulting into increase in incidence of ARI among children.
\end{abstract}

\section{Introduction}

Agriculture sector has always been the pivotal sector to the sustainable growth and development of Indian economy. During Green Revolution, high yielding variety (HYV) seeds had been introduced in the system which extensively increased the productivity, cropping intensity of land and per capita income of farmers. This induced farmers to adopt wheat-rice cropping pattern which resulted in the unsustainable use of natural resources such as soil, water and forests. After China, India is the second largest rice producing country and contributes $20 \%$ to the world rice production. Paddy production in India was 94.5 million tonne $(\mathrm{Mt})$ in 2017-18 as estimated by Ministry of Agriculture and Farmers welfare and this produced $141.75 \mathrm{Mt}$ of straw. About $40 \mathrm{MT}$ of paddy straw is generated in the north-west India of which Uttar Pradesh, Punjab, Haryana are the major contributors. Uttar Pradesh, Punjab and Haryana produced $20.67 \mathrm{Mt}$, $19.70 \mathrm{Mt}$ and 6.86Mt rice straw respectively (CESD 2017). One kilogram of paddy generates 1-1.5 kilogram of straw. In these states, about 80 percent rice straw sets to fire in fields and of the total open field burning, $48 \%$ is contributed by Punjab and Haryana alone.(Gadde et. al.,2009). This is primarily due to the short span between rice harvesting and wheat plantation. Burning of this precious raw material emits harmful particulate matters $\left(\mathrm{PM}_{10}\right.$ and $\left.\mathrm{PM}_{2.5}\right)$ and greenhouse gases (GHGs). It releases 70 percent Carbon dioxide $\left(\mathrm{CO}_{2}\right), 7$ percent Carbon monoxide (CO), 0.66 percent Methane $\left(\mathrm{CH}_{4}\right)$, and 2.09 percent Nitrogen dioxide $\left(\mathrm{N}_{2} \mathrm{O}\right)$ (Gupta et al. 2004) and have negative impact on air and soil quality and on human health. The particulate matters $\left(\mathrm{PM}_{10}\right.$ and $\left.\mathrm{PM}_{2.5}\right)$ released from burning have different intensity to affect different age group people. The weak body organs of children lead to inhale more PMs consequently their respiration rate becomes higher than other age groups. This study presents the extent of rice crop residues burning in the north-west region of India and its increasing incidence of acute respiratory infection (ARI) among children in Punjab. This paper firstly explains the objectives of the study followed by methodology, findings and discussion and lastly provides observed suggestions for to curb this menace.

\section{Objectives of the Study}

The specific objectives of this study are:

a. To explore the status of crop residues burning in northwest India 
b. To find out the impact of stubble burning on health in general and on children health in particular in Punjab

c. To put in front an inventory of suggestions to curb this menace.

\section{Methodology}

For the study, secondary sources of data have been used. On the basis of information available from estimates available from published studies, reports, internet sources, data published by Ministry of Agriculture and Farmers Welfare and National Family Health Survey (NFHS) data, an effort has been made to conduct content analysis. It has been done due to the obscurity of data on paddy straw burning and its impact on health. North-Western states remain the area of focus due to the severity of problem viz a viz other states of India.

\subsection{Findings and Discussion Crop Residue Generation and Burning}

One acre produces 2.5-3.0 metric ton paddy straw and the burning of this one acre of paddy straw can destroy $32 \mathrm{~kg}$ Urea, $5.5 \mathrm{~kg}$ Di-Amonia Phosphate (DAP) and 51 $\mathrm{kg}$ Potash manure which is already present in the residues and the soil. One third of nitrogen and sulphur, 75 percent of potash and 25 percent phosphorus present in paddy straw when contacted with heat and oxygen due to burning resulted in the emission of harmful oxides in the environment (PPCB, 2018). In India, the area under paddy is continuously increasing and therefore rice productivity and consequently rice straw production is also increasing as shown in table- 1 . In the following table- 1 , the rice straw productivity is calculated as 1.5 times of rice production. Approximately 0.08-0.8 fraction of rice straw is burnt annually in India (Gadde et. al.,2009), as a result with the increase in straw productivity its burning is also increasing which ultimately adversely affect environment and human health. During 2008-09, in India 620 million tonne (Mt) of crop residue was produced and the proportion of cereal crop residue was 58 percent of which rice alone contributed 53 percent. About 47.47 percent of total cereal crop residue is produced in the north-west India in which after Uttar Pradesh, Punjab was the major contributor to cereal crop residues (Gadde et. al. 2009). Punjab, Haryana and Uttar Pradesh produced 11.33 percent, 3.97 percent and 11.99 percent of total paddy produced in India respectively in 2015-16 as estimated by DES, MoA. The crop productivity depends on different factors such as the soil quality, amount of pesticides and fertilisers, climate, area and the quality of seed and so does the crop residues. Therefore productivity of crop residues is different in different states
Table 1. Production of Rice and Rice Straw in India.

\begin{tabular}{lll}
\hline Year & $\begin{array}{l}\text { Rice Production } \\
\text { (Million Tonnes) }\end{array}$ & $\begin{array}{l}\text { Rice Straw Production } \\
\text { (Million Tonnes) }\end{array}$ \\
\hline $\mathbf{2 0 0 8 - 0 9}$ & 99.18 & 148.77 \\
$\mathbf{2 0 0 9 - 1 0}$ & 89.09 & 133.635 \\
$\mathbf{2 0 1 0 - 1 1}$ & 95.98 & 143.97 \\
$\mathbf{2 0 1 1 - 1 2}$ & 105.30 & 157.95 \\
$\mathbf{2 0 1 2 - 1 3}$ & 105.2 & 157.8 \\
$\mathbf{2 0 1 3 - 1 4}$ & 106.7 & 160.05 \\
$\mathbf{2 0 1 4 - 1 5}$ & 105.5 & 158.25 \\
$\mathbf{2 0 1 5 - 1 6}$ & 104.4 & 156.6 \\
$\mathbf{2 0 1 6 - 1 7}$ & 110.2 & 165.3 \\
$\mathbf{2 0 1 7 - 1 8}$ & 94.5 & 141.75 \\
\hline
\end{tabular}

Source: DES, DAC \& FW, M/o Agriculture \& Farmers Welfare, $3^{\text {rd }}$ Advance Estimates.

Table-2 shows that in Uttar Pradesh $72.02 \mathrm{Mt} / \mathrm{yr}$ cereal crop residue has been produced in 2008-09 which is quite highest as compared to Punjab (45.58 percent), Haryana (24.73 percent) and other north Indian states. This table also shows that in case of biomass burnt in the north Indian states, Punjab ranked at first and in Uttar Pradesh and Haryana on an average same amount of cereal crop residue is subjected to burning.

Table 2. Cereal Crop residue Production and burnt in various North-West Indian states. (2008-09).

\begin{tabular}{lllll}
\hline (Mt/yr) & & & & \\
\hline States & $\begin{array}{l}\text { Cereal Cereal } \\
\text { crops }\end{array}$ & $\begin{array}{l}\text { Crop residues } \\
\text { biomass } \\
\text { burned }\end{array}$ & $\begin{array}{l}\text { Crop residues } \\
\text { boefficient) }\end{array}$ & $\begin{array}{l}\text { burnt(study } \\
\text { coefficient) }\end{array}$ \\
\hline $\begin{array}{l}\text { Uttar } \\
\text { Pradesh }\end{array}$ & 72.02 & $3.92-13.61$ & 22.38 & 22.25 \\
Punjab & 45.58 & $13.62-20.44$ & 13.30 & 21.32 \\
Haryana & 24.73 & $3.92-13.61$ & 6.85 & 9.18 \\
Rajasthan & 22.19 & $0.41-1.47$ & 4.27 & 2.77 \\
$\begin{array}{l}\text { Jammu and } \\
\text { Kashmir }\end{array}$ & 2.76 & $0.41-1.47$ & 0.47 & 0.23 \\
$\begin{array}{l}\text { Uttaranchal } \\
\text { Himachal }\end{array}$ & 2.40 & $0.00-0.40$ & 1.07 & 0.76 \\
Pradesh & 1.95 & $0.00-0.40$ & 0.25 & 0.42 \\
$\begin{array}{l}\text { Delhi } \\
\text { Total }\end{array}$ & 0.17 & $0.00-0.40$ & 0.04 & 0.02 \\
\hline Source & 171.8 & & 48.63 & 56.95 \\
\hline
\end{tabular}

Source: Jain Niveta et. al. 2014. 


\subsection{Emission from Paddy Straw Burning}

Stubble burning results in the unprecedented emission of dangerous particulate matters and harmful greenhouse gases (GHGs) such as Carbon dioxide $\left(\mathrm{CO}_{2}\right)$, Methane $\left(\mathrm{CH}_{4}\right)$, Carbon monoxide $(\mathrm{CO})$ and Nitrogen dioxide $\left(\mathrm{N}_{2} \mathrm{O}\right)$ and thereby posing threat to human health. Rice straw contains high ash content (18.67 percent) and high amount of silica content (74.67 percent), 15.86 percent fixed carbon, 3.01 percent Calcium oxide $(\mathrm{CaO}), 1.75$ percent Magnesium oxide ( $\mathrm{MgO}), 0.96$ percent Nitrogen dioxide $\left(\mathrm{Na}_{2} \mathrm{O}\right)$ and 12.30 percent Potassium dioxide $\left(\mathrm{K}_{2} \mathrm{O}\right)$ as shown in table-3. It can be easily assessed that paddy straw which contains these harmful elements when subjected to burning ultimately releases these elements in the environment and consequently pollute the ambient air quality.

Table 3. Proximate composition and selected major elements of ash in rice straw and in rice husk.

\begin{tabular}{lll}
\hline $\begin{array}{l}\text { Proximate analysis (percent dry } \\
\text { fuel) }\end{array}$ & Rice straw & Rice husk \\
\hline Fixed carbon & 15.86 & 16.22 \\
Volatile matter & 65.47 & 63.52 \\
Ash & 18.67 & 20.26 \\
\hline Element composition of ash (per cent) & \\
\hline $\mathbf{S i o}_{2}$ & 74.67 & 91.42 \\
$\mathbf{C a O}$ & 3.01 & 3.21 \\
$\mathbf{M g O}$ & 1.75 & $<0.01$ \\
$\mathbf{N a}_{2} \mathbf{O}$ & 0.96 & 0.21 \\
$\mathbf{K}_{2} \mathbf{O}$ & 12.30 & 3.71 \\
\hline
\end{tabular}

Source: P. Binod et. al.

$3 \mathrm{~kg} \mathrm{t}^{-1}$ particulate matter, $60 \mathrm{~kg} \mathrm{t}^{-1} \mathrm{CO}, 1460 \mathrm{~kg} \mathrm{t}^{-1}$ $\mathrm{CO}_{2}, 199 \mathrm{~kg} \mathrm{t}^{-1}$ ash and $2 \mathrm{~kg} \mathrm{t}^{-1} \mathrm{SO}_{2}$ are emitted due to straw burning (Gupta et. al., 2004). If we consider straw productivity of $141.75 \mathrm{Mt}$ in 2017 and assume that one fourth of it is burned i.e. 35.43 Mt then it resulted in the emission of approximately $106.29 \mathrm{t}$ particulate matter, $2125.8 \mathrm{t} \mathrm{CO}, 51,727.8 \mathrm{t} \mathrm{CO}_{2}, 7050.57 \mathrm{t}$ ash and 70.86t $\mathrm{SO}_{2}$. This level of emission from burning paddy straw burning is quite higher than the National Ambient Air Quality Standards (NAAQS), as demonstrated in table-4. This shows that as against the prescribed emission level, large amount of gases has been released due to burning which seriously affect not only the air quality but also human health.
Table 4. National Ambient Air Quality Standard (NAAQS).

\begin{tabular}{|c|c|c|c|}
\hline \multirow[t]{2}{*}{ Pollutant } & \multirow{2}{*}{$\begin{array}{l}\text { Time } \\
\text { Weighted } \\
\text { Average }\end{array}$} & \multicolumn{2}{|c|}{ Concentration in Ambient Air } \\
\hline & & $\begin{array}{l}\text { Industrial, } \\
\text { Residential, } \\
\text { Rural and } \\
\text { Other Areas }\end{array}$ & $\begin{array}{l}\text { Ecologically } \\
\text { Sensitive Area } \\
\text { (notified by Central } \\
\text { Government) }\end{array}$ \\
\hline $\begin{array}{l}\text { Sulphur } \\
\text { Dioxide }\left(\mathrm{SO}_{2}\right) \text {, } \\
\mu \mathrm{g} / \mathrm{m}^{3}\end{array}$ & $\begin{array}{l}\text { Annual* } \\
24 \text { hours }\end{array}$ & 5080 & 2080 \\
\hline $\begin{array}{l}\text { Nitrogen } \\
\text { Dioxide }\left(\mathrm{NO}_{2}\right) \\
\mu \mathrm{g} / \mathrm{m}^{3}\end{array}$ & $\begin{array}{l}\text { Annual* } \\
24 \text { hours }\end{array}$ & 4080 & 3080 \\
\hline $\begin{array}{l}\text { Particulate } \\
\text { Matter (size } \\
\text { less than } 10 \\
\mu \mathrm{m}) \text { or } \mathrm{PM}_{10} \\
\mu \mathrm{g} / \mathrm{m}^{3}\end{array}$ & $\begin{array}{l}\text { Annual* } \\
24 \text { hours }\end{array}$ & 60100 & 60100 \\
\hline $\begin{array}{l}\text { Particulate } \\
\text { Matter (size } \\
\text { less than } 2.5 \\
\mu \mathrm{m}) \text { or } \mathrm{PM}_{2.5} \\
\mu \mathrm{g} / \mathrm{m}^{3}\end{array}$ & $\begin{array}{l}\text { Annual* } \\
24 \text { hours }\end{array}$ & 4060 & 4060 \\
\hline $\begin{array}{l}\text { Ozone }\left(O_{3}\right) \\
\mu \mathrm{g} / \mathrm{m}^{3}\end{array}$ & $\begin{array}{l}8 \text { hours* } \\
1 \text { hour }\end{array}$ & 100180 & 100180 \\
\hline $\begin{array}{l}\text { Carbon } \\
\text { Monoxide } \\
(\mathrm{CO}) \mathrm{mg} / \mathrm{m}^{3}\end{array}$ & $\begin{array}{l}8 \text { hours* } \\
1 \text { hour }\end{array}$ & 0204 & 0204 \\
\hline $\begin{array}{l}\text { Ammonia } \\
\left(\mathrm{NH}_{3}\right) \mu \mathrm{g} / \mathrm{m}^{3}\end{array}$ & $\begin{array}{l}\text { Annual* } \\
24 \text { hours }\end{array}$ & 100400 & 100400 \\
\hline
\end{tabular}

Source: National Ambient Air Quality Standards, Central Pollution Control Board, 2009.

*Annual arithmetic means of minimum 104 measurements in a year at a particular site taken twice a week 24 hourly at uniform intervals.

\subsection{Health Implications of Stubble Burning}

Residue burning is a major source of health hazards like asthma, bronchial asthma, acute respiratory infection (ARI) and irritation in eyes. India has the highest number of blind people in the world and from every three cases of cataract in the world one is from India. Eye watering, eye irritation, conjunctival hyperemia are symptoms associated with exposure to smoke (Arbex M. et. al., 2004). The problem of Acute Respiration Infection (ARI) is particularly increasing in children due to the high respiration rate among children. The poisonous gas like Carbon Monoxide which is released due to paddy straw burning when reacted with red particles 
reduces the blood efficiency to take oxygen and generate respiratory problems. Similarly, the emitted Carbon dioxide creates irritation in eyes and the oxides of Sulphur dioxide and of Nitrogen directly badly affect lungs, blood, skin and respiratory activities which can generate cancer like diseases (Punjab Pollution Control Board, 2018). As per a study conducted by Punjab Pollution Control Board, 425 milligram per cubic meter respirable fine particles are released during the period of paddy straw burning as against 60 milligram per cubic meter in normal days. The following figure-1 shows the Air Quality Index (AQI) with its possible health impacts. It scales the air quality in terms of good, satisfactory, moderate, poor, very poor and severe levels. The first three levels of air quality have minor impact on health and create breathing discomfort but the last three levels of air quality not only affect the people already suffering from respiratory diseases but also adversely affect healthy people. During the period of harvesting of paddy and burning of straw the air quality is severe instead of satisfactory as in normal days. Gupta et. al. in 2017, estimated the effect of PMs emitted during the period of burning on the working of different physiological parameters of children. This study found that the trends of fall in respiratory parameters were alarming especially for the subjects with lower and higher Body Mass Index (BMI) during crop residue burning period.

\begin{tabular}{|c|c|c|c|}
\hline AQI & Remark & Color Code & $\begin{array}{l}\text { Possible Health } \\
\text { Impacts }\end{array}$ \\
\hline $0-50$ & Good & & Minimal impact \\
\hline $51-100$ & Satisfactory & & $\begin{array}{l}\text { Minor breathing } \\
\text { discomfort to } \\
\text { sensitive people }\end{array}$ \\
\hline $101-200$ & Moderate & & $\begin{array}{l}\text { Breathing discomfort } \\
\text { to the people with } \\
\text { lungs, asthma and } \\
\text { heart diseases }\end{array}$ \\
\hline $201-300$ & Poor & & $\begin{array}{l}\text { Breathing discomfort } \\
\text { to most people on } \\
\text { prolonged exposure }\end{array}$ \\
\hline $301-400$ & Very Poor & & $\begin{array}{l}\text { Respiratory illness on } \\
\text { prolonged exposure }\end{array}$ \\
\hline $401-500$ & Severe & & $\begin{array}{l}\text { Affects healthy } \\
\text { people and seriously } \\
\text { impacts those } \\
\text { with existing diseases }\end{array}$ \\
\hline
\end{tabular}

Figure-1. Air Quality Index (AQI).

Source: Central Pollution Control Board. Microgram per cubic meter.

These fine particles cause respirable diseases such as asthma, cough, lung cancer etc. and are dangerous for the lives of children and pregnant women. Table-5 shows that the problem of acute respiratory infection is relatively high in Uttar Pradesh, Punjab and Haryana as compared to Himachal Pradesh which indicates that this may be due to the extensive burning of biomass in these states. The fieldwork of NFHS-4 was conducted in the rabi season in the respective states which shows that the problem of ARI is extreme in this season, this problem will definitely be very intense in the kharif season. A recent study regarding the implication of pollution due to stubble burning on health and pulmonary functions, conducted by Dr. Vitul K. Gupta in Bathinda and its neighboring districts in Malwa region of Punjab revealed a significant increase in the health disorders among normal people and particularly those who suffered from Chronic Obstructive Pulmonary Disorder (COPD) after stubble burning (29 September, 2018, Times of India). Out of total 8,573 respondents, 84.5 percent respondents suffered from health problems due to smoke and in all, 76.8 percent respondents reported irritation in eyes (24 January, 2016, Times of India).

Table 5. Percentage of Children Under age five with the Symptoms of ARI.

\begin{tabular}{lll}
\hline State & Male & Female \\
\hline Punjab & 4.8 & 3.3 \\
Haryana & 3.3 & 3.0 \\
Himachal Pradesh & 1.6 & 1.7 \\
Uttar Pradesh & 5.0 & 4.3 \\
Total & 14.7 & 12.3 \\
\hline
\end{tabular}

Source: National Family Health Survey-4, 2015-16.

Straw burning not only directly affect the environment and health it also enhances the health expenses and reduce productivity in an economy. In 2010, Kumar P. et. al. demonstrated that Rs 76 million is the monetary value of health damages caused by air pollution due to stubble burning and found that this estimate could be higher if expenses on preventive activities, loss in productivity and loss in utility are considered.

Based on different studies and news reports on stubble burning and its implications on respiratory health, it can be inferred that burning is not only affecting the people residing near the site but also affecting the people residing far away from that site due to the presence of smoke in the air.

\section{Inventory of Suggestions}

There are two basic reasons of crop residue incineration by farmers, the major one is time lag between the rice harvesting and wheat crop sowing is very short and during this short period of time burning is the most cheapest way 
to dispose of the straw and the second is the scarcity of affordable alternatives to straw burning. As a result straw is subjected to burning which ultimately causes pollution in the air and affects human health badly. There is an urgent need to address this problem and to save environment and human health. For this, an inventory of suggestions has been presented in two different aspects: technological options and non-technological options.

\subsection{Crop Residue Management}

\subsubsection{Technological Options}

Fodder and Compost: when straw is mixed with urea then it can be used as a fodder for animals. But this is not a viable option due to the presence of high amount of silica and low amount of lignin which make it hard to digest for animals. Compost can be made from it and can be used to produce mushroom.

Cardboard and Paper Industry: paddy straw can be used in the cardboard and paper industry. It helps to protect trees from harvesting for paper industry. Although a very less amount of straw can be consumed in this operation but along with other alternatives this may be considered.

In-situ management: an important alternative is to incooperate straw in the soil which helps to maintain the soil nutrient content and its organic matter. There are many machines available for that such as rotavators, choppers, happy seeder etc. Rotavator chopped the straw into small pieces and sow it into the soil but straw is difficult to decay within 20-25 days. Happy seeder do triplet work, it not only harvest the crop and chopped the straw but it also sow the wheat seeds and mulch the chopped straw into the soil which helps to maintain the moisture content into the soil. But this option has its own limitations such as due to the presence of straw in the soil, nitrogen will become immobile and consequently the wheat crop suffers from nitrogen deficiency, it also generates weeds and subsequently large amount of fertilisers and pesticides have to be used. This process consumes more energy and diesel, so from an economic point of view also this is not a good option.

Power generation: biomass pellets can be made from this residue and can be used in biomass based power plants for power generation. It is estimated that agriculture residues alone substitute 25 percent of coal consumption in the generation of electricity and consequently reduce the coal import burden. This also helps to employ 5000 persons for the biomass pellet plant construction and approximately 200,000 permanent jobs in the process of collection and transportation of straw, pellet production of straw and then its use in power plant (Purohit P. and Chaturvedi V, 2016).
This is not an environmentally viable option since it also pollutes environment by emitting various harmful gases.

Biogas Production: biogas and bio char can also be produced from the biomass. In the production of biogas from the straw, grinders are used to chop it in small pieces and the put it in digesters along with other waste. This is completely an anaerobic process and it not only produces biogas but also produces liquid and solid organic fertilisers as by-products. With an appropriate pre-treatment of straw, bio-ethanol can be produced which is used in petrol production. It would also help to reduce the import bill.

Biofuel Production: biofuel can also be produced by using paddy straw. In its production process, straw is heated at a high temperature which results in the production of a gas which after extracting some gases from it such as $\mathrm{CH}_{4}, \mathrm{CO}_{2}$, etc. generates oil. This oil can be used in Cars and other vehicles.

\subsubsection{Non-Technological Options}

Diversification of Agriculture: in order to maintain agricultural sustainability it is necessary to adopt the idea of diversification. Rice-Wheat cropping system is an unsustainable system as water level is depleting and environment is polluting. Along with these crops, maize, sugarcane etc. can be produced. It helps the soil to maintain its fertility, moisture and nutrition.

Education and Awareness: the other non-technological alternative to take away farmers from burning is to educate and aware them through various campaigns and programmes. They should be aware regarding the available alternatives and also be informed about the adverse effects of burning

Incentives to Farmers: in order to encourage the use of rotavator, happy seeder, super straw management system (SMS) like machines, farmers can be incentivised with the provision of adequate subsidy on the purchase of these machines. In a recent initiative by the government of Punjab, a two year plan has been framed which includes expenditure of Rs 665 crore to provide 80 percent subsidy on straw management machinery to cooperative societies and groups and 50 percent subsidy to individual farmers (Manish Sirhindi, TOI, August 30, 2018 ). This amount of subsidy is not adequate since before the provision of subsidy the rotavator nearly costs Rs 60,000 and after government strict ban on burning the demand of the machine increases and its price also shoot up to approximately 1, 30,000 and with 50 percent subsidy it costs to them of Rs 65,000 which is a very expensive deal. In this case, residue burning is the cheapest and easiest way to dispose the straw. Therefore an adequate amount of subsidy is required to encourage farmers regarding the adoption of other available alternatives. 
Investment in Research and Development: there is a great need to invest in research projects which will deal with this issue. In this respect, scientific as well as socio-economic study is required so that a viable option can be found out. Punjab Agriculture University (PAU) released different nonbasmati varieties such as PR 121, PR 122, PR 123, PR 124 and PR 126 which mature one to five weeks earlier than the earlier popular varieties like PR 118 and Pusa 44 which takes 150-160 days to mature. This kind of helpful outcomes can be made through huge investment in research projects.

Stringent Laws and Enforcement Mechanism: strict government regulation and enforcement mechanism is required so that this problem can be solved. In 2016, 80,879 cases of crop residue burning were recorded and an environmental compensation of Rs 73.22 lakh was imposed. However, a mere Rs 14.05 lakh could be recovered. In 2017 , 43,814 such cases were recorded and fined Rs 72.62 lakh but only 5.51 lakh could be collected (5 October, 2018, Times of India).

Market for straw: like the purchase of crops, there should also be an appropriate purchase mechanism for the straw. Particular market mechanism should be there which assures farmers regarding the procurement of the residue and keep away them from this activity of menace.

\section{Acknowledgement}

The part of this paper is presented in " $19^{\text {th }}$ APG Meet and International Conference" held on November 2-3, 2018. I am grateful to Dr. Shaik Iftikhar Ahmed for his insight and expertise that greatly assisted this research. I sincerely acknowledge the contribution of Dr. Neetu Gaur and Dr. Gurinder Kaur for their valuable suggestions.

\section{References}

Arbex M. et. al., (2004). Biomass burning and its effects on health. Journal Brasileiro de Pneumologia, 30(2), 1806-3756.
Binod P. et. al., (2009). Bioethanol production from rice straw: An Overview. Bioresource Technology. 101, 4767-4774.

Chandra R, et. al.,(2017). Energy Generation from paddy straw: An Analysis of Bioenergy Models. Akshay Urja, MNRE, Government of India. 22-27.

Gadde et. al. (2009). Rice straw as a renewable energy source in India, Thailand, and the Philippines: Overall Potential and Limitations for Energy Contribution and Greenhouse Gas Mitigation. Biomass bioenergy. 33, 1532-1546.

Gupta S. et. al.,(2017). Respiratory health of school children in relation to their body mass index (BMI) during crop residue burning events in North Western India. MAPAN-Journal of Metrology Society of India 33(2), 113-122.

Jain Niveta et. al. (2014). Emission of air pollutants from crop residue burning in India. Aerosol and Air Quality Research. 14, 422-430.

Kumar P. and Kumar S, (2010). Valuing the health effects of air pollution from agricultural residueburning. Retrievedfrom citeseerx.ist.psu.edu/viewdoc/downloa $\mathrm{d}$ ? $\mathrm{doi}=10.1 .1 .193 .6868 \& \mathrm{rep}=$ rep $1 \&$ type $=$ pdf.

Manish S. (2018). Punjab puts in place multi-crore action plan to tackle stubble burning. Retrieved from https:// timesofindia.indiatimes.com.

Mohan. V. (2018). Stubble burning hits health adversely, confirms study. Retrieved from https://timesofindia. indiatimes.com.

National Air Quality Index, Central Pollution Control Board. Retrieved from https://app.cpcbccr.com/ AQI_Indial Web source:http://rchiips.org/nfhs/ https://timesofindia.indiatimes.com.www.ppcb. gov.in/Attachments/Stubblepercent20Burning/ stubblepercent20burning.pdf. http://cpcb.nic.ins. 